\title{
Plantain seed production in a radial trial
}

\begin{abstract}
Plantain (Plantago lanceolata) was grown in a radial trial in order to investigate the effect of plant density on seed production. Plant densities ranged from 278 plants $/ \mathrm{m}^{*}$ to 17 plants $/ \mathrm{m}^{\prime}$ in 9 arcs. Plants were monitored and harvested individually, thus giving effective high replication (32). Decreasing plant density had a significant positive effect on seed head production (both numbers and size of head), seed yield and plant vigour. Highest seed yield was associated with a density of 17 plants $/ \mathrm{m}^{2}$.
\end{abstract}

K eywords plantain, seed production, plant density, competition, radial trial design

\section{Introduction}

Increasing interest in low input agriculture and organic farming has revived interest in pasture herbs. Herbs are thought to have particular value, as they tend to have a higher mineral concentration than grasses.

Plantain (Plantago lanceolata), also known as ribgrass, has been $\overline{\text { recognnised }}{ }^{-}$as a useful component of pasture swards for many years. It is tap-rooted and is a good source of calcium, sodium, phosphorus and potassium plus trace elements, particularly copper and cobalt (Thomas \& Thompson 1948).

Plantain is a new species in agricultural research in New Zealand and very little is known about requirements for seed production. Research in the US under glasshouse conditions show that plantain is a long-day plant. It is also known that plantain has a long flowering season which, beginning in April in the northern hemisphere, is curtailed by frost (Sagar \& Harper 1964) and competition (Sagar \& Harper 1961).

The trial reported here investigated the effect of plant density on plantain seed production in New Zealand.

\section{Method}

In order to maximise the information that could be gained from minimum seed and land area, a systematic radial spacing trial designed by Nelder (1962) was used. Radial trials have been used with success for plants such as maize (Dyson \& Douglas 1975; Wallace \& Davies 1976) but have not been used in herbage seed research.

Plantain plants were reared in the glasshouse, hardened off, and planted out in mid-September into Wakanui silt loam (Udic Ustrochrept) at Lincoln. Plants were spaced at increasing intervals (from 60 $\mathrm{mm}$ to $283 \mathrm{~mm}$ ) along 32 radii (Figure 1). Plant densities ranged from $17 \mathrm{plants} / \mathrm{m}$ ' to 278 plants $/ \mathrm{m}^{*}$ in 9 concentric circles. The ratio of radii of successive cirlces was 1.19 and of successive densities $(1.19)^{2}=$ 1.42. Each spacing was replicated 32 times in the trial, as each plant was monitored individually. This amount of replication was considered necessary as herbs are highly variable in morphology. The trial was surrounded by a buffer zone of spaced plants and the area was irrigated when necessary to prevent moisture stress.

Plants were monitored weekly. Flowering heads were counted and ripe heads harvested by hand. Seed yield and head size were determined for the peak harvest (i.e., the harvest at which most heads were collected). Heads were considered to be ripe when seeds turned brown (having been green and then purple) and stems turned brown and became slightly withered below the seed head.

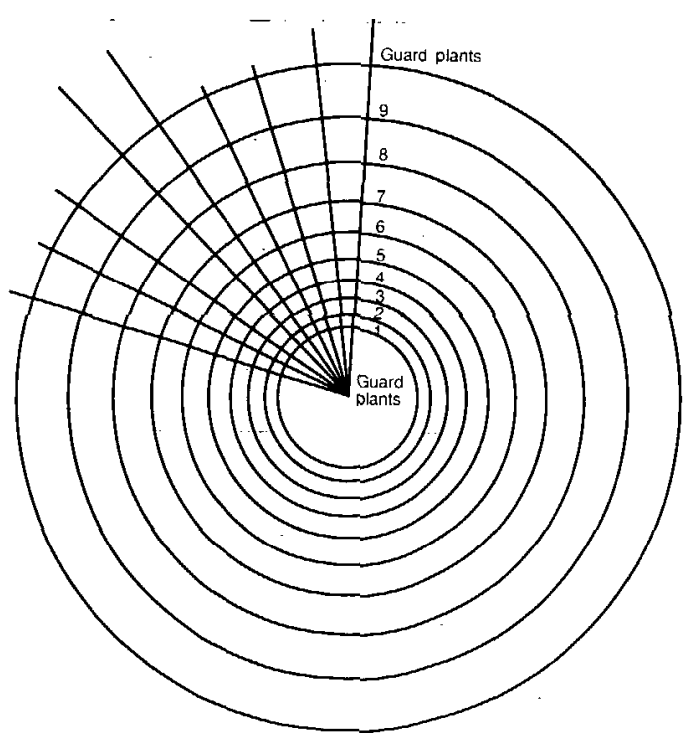

Figure 1 Radial trial design for plantain seed production3 Plants are at intersection of circles and radii. 


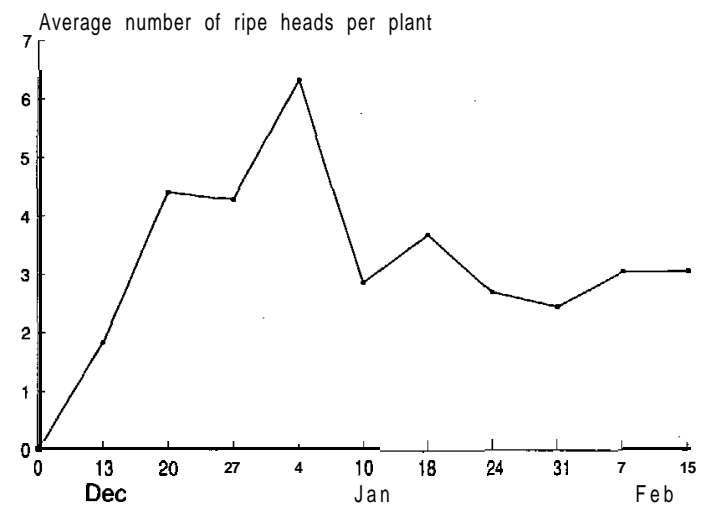

Figure 2 Seasonal pattern of ripe head production in Canterbury.

\section{Results and discussion}

Plantain heads started flowering in mid-October. These first heads were ready for harvest in midDecember (Figure 2). The 8-week period between flowering and harvest is consistent with results from an earlier trial investigating the optimum time of seed harvest (Rowarth \& Rolston 1991). Flowering was curtailed by frosts in April but harvesting was discontinued in mid-February when the stand suffered from the fungus Phomopsis subordinaria.

This fungus attacks the base of seed heads, entering through mechanical damage caused by feeding insects (de Nooji \& van der Aa 1987), and preventing seed fill (Grove 1935; de Nooij \& van der Aa 1987;

Farr et al. 1989). The prevalence of the fungus within the trial is probably an artefact, in that harvesting required movement through the plants. This could cause head damage and would have assisted in the spread of the fungus. For this reason and because the fungus did not appear until after peak harvest, it is not thought to pose a problem to potential plantain seed growers. This is supported by observation of plantain stands adjacent to the radial trial and in Palmerston North where $\boldsymbol{P}$. subordinaria had not attacked sufficient heads by time of harvest to warrant investigation and was apparent on less than $5 \%$ of heads by the end of autumn.

Table 1 Ripe head production as affected by spacing and harvest date.

$$
\text { Plants/m' }
$$

$\begin{array}{llllllllll}\text { Harvest date278 } & 198 & 138 & 98 & 69 & 49 & 35 & 24 & 17\end{array}$

\begin{tabular}{|c|c|c|c|c|c|c|c|c|c|}
\hline 13.12 .89 & 1 & 1 & 1 & 1 & 2 & 2 & 3 & 2 & 4 \\
\hline 20.12.89 & 2 & 2 & 2 & 3 & 5 & 5 & 7 & 7 & 8 \\
\hline 27.12 .89 & 1 & 1 & 1 & 3 & 3 & 4 & 7 & 9 & 10 \\
\hline 4. 1.90 & 2 & 2 & 2 & 3 & 6 & 5 & 10 & 12 & 15 \\
\hline $\begin{array}{l}0.190 \\
0.1 .0\end{array}$ & 1 & 1 & 0 & 2 & 2 & 3 & 5 & 5 & 6 \\
\hline 18.1 .90 & 1 & 1 & 1 & 2 & 2 & 3 & 6 & 7 & 10 \\
\hline 24.1 .90 & 1 & 0 & 1 & 1 & 1 & 2 & 4 & 6 & 9 \\
\hline 31.1 .90 & 0 & 0 & 0 & 1 & 0 & 2 & 4 & 6 & 9 \\
\hline 7.2 .90 & 1 & 0 & 0 & 1 & 1 & 2 & 5 & 6 & 11 \\
\hline 15.2 .90 & 0 & 0 & 0 & 0 & 2 & 4 & 6 & 7 & 9 \\
\hline
\end{tabular}

Peak harvest occurred on 4 January 1990: the average number of ripe heads per plant at this harvest was significantly $(\mathbf{P}<0.01)$ greater than at any other harvest (Figure 2).

The effect of spacing on seed head production can be seen in Table 1. Fewer seed heads were produced at high planting densities than from low planting densities. This effect was significant $(\mathbf{P}<0.01)$ at all harvests. Head numbers from spacings of 278-49 plants $/ \mathrm{m}^{2}$ were highest for harvest 2 and 4 . Head numbers from spacings of 35-17 plants/m' peaked at harvest 4 and were also high for harvest 6 . Thus at high plant densities seed production occurred earlier and finished more quickly than at low plant densities. Whereas head production continued until April in the widely spaced plants, many plants in the dense areas did not survive competition and died. This is consistent with overseas experience with plantain (Sagar \& Harper 1961, 1964).

Heads collected at peak harvest (4 January 1990) were used for more detailed analysis. A linear relationship was derived between planting distance and numbers of ripe heads (numbers of ripe heads = 0.127 distance $-0.198 ; 96.2 \%$ variance accounted for) (Figure 3). Head length (Figure 3), seed yield/head and seed yield/plant (Figure 4) increased with increasing planting distance. The increase in seed yield/plant was primarily a function of increase in head numbers (Figure 3).

Head length $(\mathrm{cm})$ and ripe heads/plant

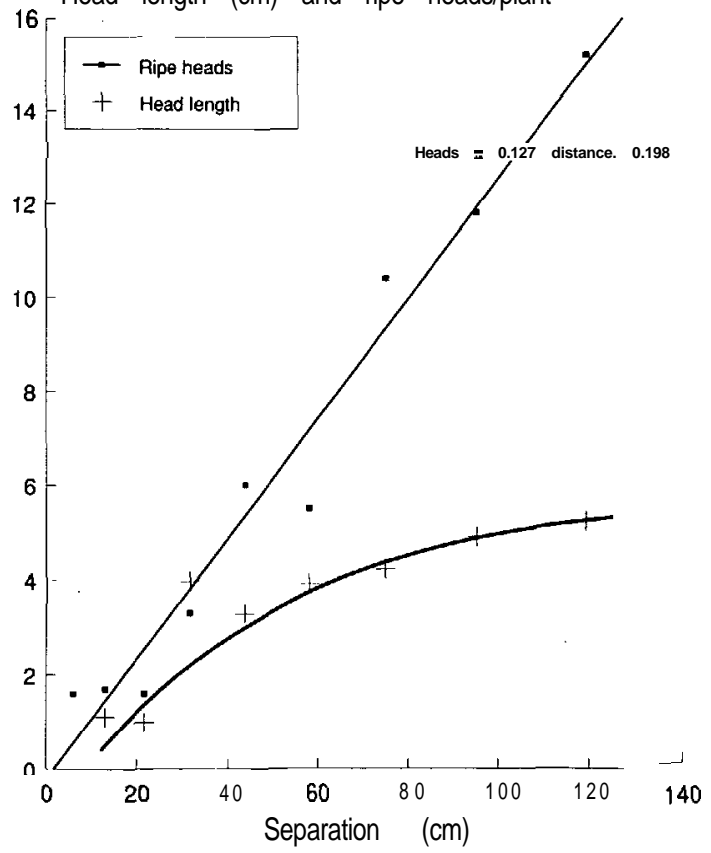

Figure 3 Effect of plant density (increasing separation) on head size and numbers of heads per plant in plantain. 


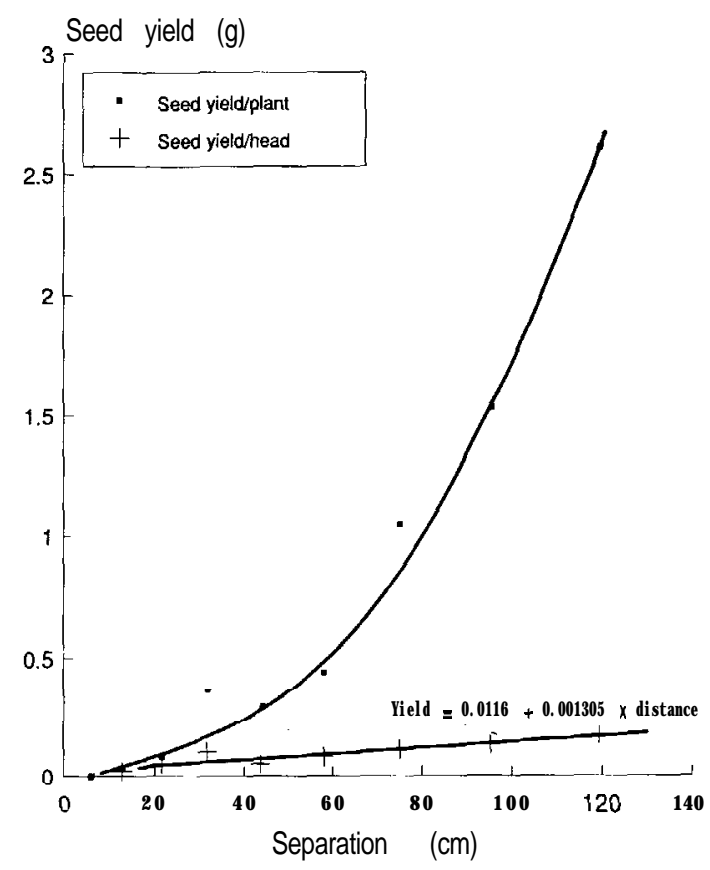

Figure 4 Effect of plant density (increasing separation) on plantain seed yield per head and per plant.

Seed yreld per plant data were used to calculate seed yield $\left(\mathrm{g} / \mathrm{m}^{\prime}\right)$. A linear relationship was derived between seed yield and planting distance (yield = $5.59+0.3503$ distance; $71.6 \%$ variance accounted for) (Figure 5). The highest yield $\left(45 \mathrm{~g} / \mathrm{m}^{*}\right)$ was from a planting density of 17 plants $/ \mathrm{m}^{*}$ which equates to a plant every $20 \mathrm{~cm}$ in $30 \mathrm{~cm}$ rows. At a thousand-seed weight-of $1.55 \mathrm{~g}$, this density-could-be-achievedwith $\overline{\mathbf{a}}$ sowing rate of $0.26 \mathrm{~kg} / \mathrm{ha}$. Seed yields of $37 \mathrm{~g} / \mathrm{m}^{2}$ were produced.from planting densities of 24 and. 35 plants $/ \mathrm{m}^{2}$ (the latter density equates to a plant every $20 \mathrm{~cm}$ in $15 \mathrm{~cm}$ rows). These densities could be achieved with sowing rates of 0.38 and $0.54 \mathrm{~kg} / \mathrm{ha}$ respectively.

Although the highest seed yield came from the most widely spaced plants, densities of 17 and 24 plants $/ \mathrm{m}$ ' did not provide total ground cover, whereas planting densities of 35 or more plants $/ \mathrm{m}$ ' did. Bare ground can result in problems with weed competition and moisture loss, as has been noticed with chicory grown for seed production (Hare et al. 1991).

\section{Conclusions}

The radial trial proved a successful method of monitoring the effect of plant density on plantain seed production.
Seed yield per plant is strongly related to number of seed heads per plant. The latter increases with dereasing plant density. To maximise seed production, growers should sow plantain at a rate resulting in $17-35$ plants $/ \mathrm{m}^{2}(0.26-0.54 \mathrm{~kg} / \mathrm{ha}$ at $100 \%$ germination; $0.37-0.77 \mathrm{~kg} / \mathrm{ha}$ at $70 \%$ germination). This could be achieved with a precision drill. Using the higher rate of seed is advised as a planting density of 35 plants $/ \mathrm{m}^{2}$ gave total ground cover. Furthermore, seed and seedling failure will result in a less than predicted plant density.

Intensive monitoring of the radial trial enabled extrapolation of harvest dates to a larger area of plantain. Seed yield from the area harvested on 21 December 1989 (8 weeks after the first mass flowering, and coinciding with the first harvest in the radial trial) was $335 \mathrm{~kg} / \mathrm{ha}$. This was consistent with the yield of $400 \mathrm{~kg} / \mathrm{ha}$ achieved the previous year from a plantain stand not managed for seed production (Rowarth \& Rolston 1991). However, the average seed yield from the area harvested on 4 January 1990 (coinciding with peak harvest in the radial trial) was over $600 \mathrm{~kg} / \mathrm{ha}$.

\section{ACKNOWLEDGEMENTS}

The assistance of Mr W.J. Archie with data collection and of Mr A.R. Wallace for initial discussion on the use of the radial design is acknowledged with gratitude.

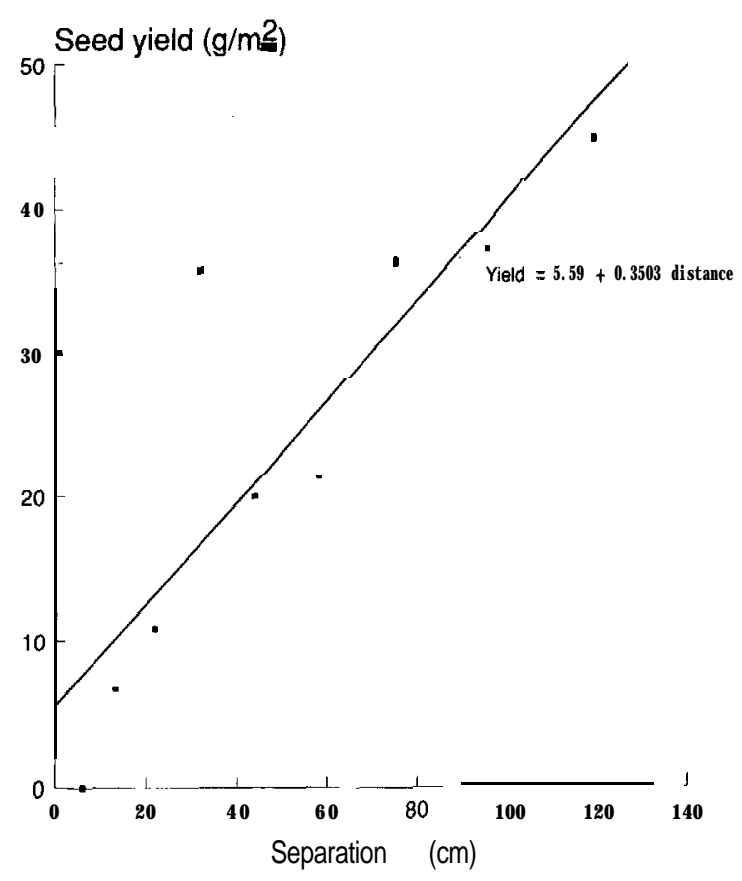

Figure $\mathbf{5}$ Effect of plant density (increasing separation) on plantain seed yield $\left(\mathrm{g} / \mathrm{m}^{2}\right)$. 


\section{REFERENCES}

de Nooij, M.P.; van der Aa, H.A. 1987. Phomopsis subordinaria and associated stalk disease in natural populations of Plantago lanceolata. Canadian journal of botany 65: 2318-2325.

Dyson, C.B.; Douglas, J.A. 1975. Comparison of systematic spacing and randomised block designs in a maize population study. Proceedings of the Agronomy Society of New Zealand 5: 45-48.

Farr, D.F.; Bills, G.F.; Chamuris, G.P.; Rossman, A.Y. 1989. Fungi on plants and plant products in the United States. St Paul, APS Press. $1252 \mathrm{pp}$.

Grove, W.B. 1935. British stem and leaf fungi (Coelomycetes). Vol. 1. Sphaeropsidales. Cambridge, Cambridge University Press. 488 pp.

Hare, M.D.; Rowarth, J.S.; Archie, W.J.; Rolston, M.P.; Guy, B.R. 1991. Chicory seed production: research and practice. Proceedings of the NZ Grassland Association 52: this issue.

Nelder, J.A. 1962. Systematic designs for spacing experiments. Biometrics 18; 282-307.

Rowarth, J.S.; Rolston, M.P. 1991. Optimum time of harvesting for plantain (Plantago lanceolata) grown for seed. Journal of applied seedproduction (in press).

Sagar, G.R.; Harper, J.L. 1961. Controlled interference with natural populations of Plantago lanceolata, $P$. major and $P$. media. Wheat research 1: 163-l 76.

Sagar, G.R.; Harper, J.L. 1964. Biological flora of the British Isles. Journal of ecology 52: 189-221.

Thomas, B.; Thompson, A. 1948. The ash-content of some grasses and herbs on the Palace Leas hay plots at Cockle Park. The Empire journal of experimental agriculture 16: 221-230.

Wallace, A.R.; Davies, D.J.G. 1976. Maize densities for forage production in Canterbury. Proceedings of the Agronomy Society of New Zealand 6: 37-42. 